\title{
UPAYA MENINGKATAN KETRAMPILAN MEMBACA SERTA MENULIS ANAK MELALUI METODE PERMAINAN KARTU HURUF DAN KARTU KATA DI TK PKK PUTRAGIRI KULON PROGO
}

\author{
Oleh : Sugiyati \\ Guru TK PKK Putragiri
}

\begin{abstract}
The reading and writing ability among children is still low. The children do not know letters and words yet, so that the letter card game in reading and writing activities for children at imitating level is expected to improve student's reading and writing ability. The subject of this classroom action research was class B students in Putragiri PKK Kindergarten of 2018/2019 academic year. The data collection techniques was observation to measure the scale of reading and writing ability among students. This study conducted in two cycles. Cycle I was held on January 2019, carrying out the national day theme in the form of props story books, worksheets, student magazines, pictures, etc. After cycle I, reflection was done to plan cycle II, which be held on August 2019 with the religious holidays theme and the sub-theme was Qurban and the Idhul Adha day. The results of the study describe that 1) the reading and writing ability among children before being given an action were in the substantial category that means began to develop, 2) the letter card games can improve children's reading and writing skills.
\end{abstract}

Keywords: reading ability, writing ability, game, letter cards, word cards

\section{PENDAHULUAN}

Pendidikan adalah investasi jangka panjang yang memerlukan usaha dan dana yang cukup besar, hal ini diakui oleh semua orang atau suatu bangsa demi kelangsungan masa depannya. Demikian halnya dengan bangsa Indonesia menaruh harapan besar terhadap pendidik dalam perkembangan masa depan, karena dari sanalah tunas muda harapan bangsa sebagai generasi penerus dibentuk. Keberhasilan pendidikan memang ditentukan oleh beberapa faktor, antara lain: siswa, orangtua, masyarakat, pemerintah serta guru yang profesional. Salah satu faktor penentu keberhasilan pembelajaran adalah kemampuan guru dalam merencanakan dan melaksanakan pembelajaran yang efektif, sebab pembelajaran yang efektif tidak dapat muncul dengan sendirinya tetapi guru harus pandai menciptakan kondisi pembelajaran yang memungkinkan siswa aktif, sehingga tujuan pembelajaran yang telah ditetapkan dapat tercapai optimal. (Suciati, dkk. 2010)

Dengan disahkannya Undang-undang no 20 tahun 2003 tentang Sistem Pendidikan Nasional oleh pemerintah merupakan bukti komitmen bangsa Indonesia untuk menyelenggarakan pendidikan anak usia dini. Disebutkan secara tegas dalam Undangundang tersebut bahwa Pendidikan Anak Usia Dini (PAUD) adalah suatu upaya pembinaan yang ditujukan kepada anak sejak lahir sampai dengan usia enam tahun yang dilakukan melalui pemberian rangsang pendidikan untuk membantu pertumbuhan dan perkembangan jasmani dan rohani agar anak memiliki kesiapan dalam memasuki pendidikan lebih lanjut (ps 1 butir 14).

Menurut Budhiastuti (2013) waktu yang paling tepat untuk belajar membaca pada anak adalah saat dia memasuki TK. Pada masa ini rasa ingin tahu anak berkembang sehingga anak banyak melontarkan pertanyaanpertanyaan mereka juga sudah lebih siap menerima hal-hal yang dilihat di sekolah. Di samping itu kemampuan mereka berkembang menjadi lebih abstrak. Untuk itu anak sudah dapat dilihatkan pada simbol (Reni Akbar dan Hadawi 2010).

Ketrampilan Membaca serta menulis anak mulai terlihat menonjol saat usia 5-7 tahun, yaitu ketika anak memasuki pendidikan 
TK pada kelompok B. Pada usia tersebut anak mulai sering bertanya dan mencontoh huruf serta kata, belajar menulis misalnya namanya sendiri, nama ayah dan ibunya. Serta mencontoh huruf yang ditempel di dalam kelas. Misalnya ; pa-pan tu-lis lo-ker, kur-si, bu-ku, me-ja, a-pel, dsb.Dalam meningkatkan Ketrampilan Membaca serta menulis bagi anak TK yang perlu dipikirkan adalah metode, tehnik dan alat peraga apa yang dapat digunakan, sebab bila terjadi kesalahan dalam penerapan metode dan alat peraga yang terjadi bukanlah pencapaian prestasi melainkan suatu bentuk penekanan yang akan berdampak pada pembentukan perkembangan anak.

Berdasarkan pengamatan awal atau Pra Siklus dalam pembelajaran bahwa Tahun Pelajaran 2018/2019 jumlah siswa TK PKK Putragiri Desa Giripurwo, Kecamatan Girimulyo Kabupaten Kulon Progo berjumlah 45 anak .terdiri dari kelompok A ada 20 anak dan kelompok B ada 25 anak, disini kami akan meneliti anak kelompok B karena anak tersebut dimungkinkan akan lulus dan melanjutkan ke SD sehingga perlu penanganan yang khusus.

Hasil Pengamatan awal atau pra siklus dari 25 anak tersebut ada 2 anak atau $8 \%$ yang memiliki ketrampilan membaca amat baik, dan ada 8 anak atau $32 \%$ anak memiliki ketrampilan membaca baik dan ada 10 anak atau $40 \%$ yang memiliki ketrampilan membaca cukup serta ada 5 anak atau 20\% yang memiliki ketrampilan membaca kurang.

Dari 25 anak tersebut ada 6 anak atau $24 \%$ yang memiliki ketrampilan menulis amat baik dan ada 6 anak atau 24\% anak ketrampilan menulis baik dan ada 9 anak atau $36 \%$ yang ketrampilan menulis cukup serta ada 4 anak atau $16 \%$ yang memiliki ketrampilan menulis kurang.

Dari 25 anak tersebut ada 4 anak atau $16 \%$ yang sangat aktif dalam bermain kartu kata dan kartu huruf dan ada 9 anak atau 36\% anak yang aktif dalam bermain kartu kata dan kartu huruf dan ada 6 anak atau 24\% yang kurang aktif dalam bermain kartu kata dan kartu huruf serta ada 6 anak atau 24\% yang belum aktif atau tidak aktif bahkan tidak mau untuk bermain kartu kata dan kartu huruf.

Berdasarkan hasil data tersebut di atas maka penulis berusaha meningkatkan ketrampilan membaca serta menulis anak di TK PKK Putragiri Semester II Tahun Pelajaran 2018/2019 melalui Penelitian Tindakan Kelas.

Berdasarkan identifikasi masalah dan pembatasan masalah tersebut diatas maka dirumuskan masalah sebagai berikut: Apakah melalui metode permainan kartu huruf dan kartu kata dapat meningkatkan ketrampilan membaca serta menulis anak di TK PKK Putragiri Semester II tahun ajaran 2018/2019?

Penelitian ini bertujuan untuk meningkatkan ketrampilan membaca serta menulis anak melalui metode permainan kartu huruf dan kartu kata di TK PKK Putragiri Semester II tahun ajaran 2018/2019

\section{Ketrampilan Membaca}

Membaca adalah kegiatan yang melibatkan unsur auditif (pendengaran), dan visual (pengamatan), sedangkan ketrampilan dan perbuatan) yang dapat dipahami oleh orang lain. menurut Depdiknas (2007) Ketrampilan membaca adalah Ketrampilan anak untuk dapat mengungkapkan sesuatu melalui tulisan, gambar ataupun coretan.Membaca merupakan Kegiatan yang melibatkan unsur auditif (pendengaran) dan visual (pengamatan).

Menurut Depdiknas (2007) ketrampilan membaca merupakan ketrampilan yang dilakukan anak dengan memggunakan kemampuan linguistik (bahasa) anak secara keseluruhan.Ketrampilan membaca meliputi kemampuan mendengar, melihat dan memahami berbicara dan membaca gambar.

Dari uraian diatas dapat diambil kesimpulan bahwa Ketrampilan membaca adalah suatu kemampuan yang dilakukan oleh anak dapat ditunjukkan oleh anak dalam perilaku: mengucapkan sesuatu yang 
diperdengarkan melalui latihan membaca baik berbentuk buku maupun tulisan dimana lingkungan termasuk di dalamnya peran orang tua dan guru. seharusnya menciptakan berbagai aktivitas bermain sederhana memberikan arah dan bimbingan agar berbagai potensi yang tampak akan tumbuh berkembang secara optimal.

\section{Ketrampilan Menulis Anak}

Menurut Depdiknas (2007) Menulis merupakan ekspresi/ungkapan dari bahasa lisan kedalam suatu bentuk goresan/coretan. kegiatan awal menulis dimulai ketika anak pura pura menulis diatas kertas, pasir atau media lainnya dalam bentuk coret-coretan sampai anak mampu menirukan bentuk tulisan yang sesungguhnya.

\section{Metode Permainan Kartu Huruf dan Kata}

Dalam pengembangan ketrampilan membaca di TK terdapat beberapa pendekatan yang dilakukan melalui berbagai bentuk permainan antara lain metode Sintesis, metode global dan metode Whole-linguistic. Metode sintesis yang didasarkan pada teori asosiasi memberikan suatu pengertian bahwa suatu unsur akan bermakna apabila unsur tersebut bertalian atau dihubungkan dengan unsur lain sehingga membentuk suatu arti (Dhieni, 2012).

Unsur huruf tidak akan memiliki makna apa-apa kalau tidak bergabung (sintesis) dengan unsur (huruf) lain sehingga membentuk suatu kata, kalimat atau cerita yang bermakna. Atas dasar itu maka penulis mengajukan permainan membaca yang dimulai dari unsur huruf di sini dengan menggunakan bantuan gambar pada setiap kali memperkenalkan huruf misalnya huruf "a" disertai gambar ayam , angsa, anggur, apel (Dhieni, 2012)

Selain metode di atas terdapat ketrampilan membaca pada anak dapat dilakukan dengan menggunakan metode global. Metode ini didasarkan pada teori ilmu jiwa keseluruhan (gestalt). Dalam metode ini anak pertama kali memakai segala sesuatu secara keseluruhan. Keseluruhan memiliki makna yang lebih dibandingkan dengan unsurunsurnya. Kedudukan setiap unsur, hanya berarti jika memiliki kedudukan fungsional dalam suatu keseluruhan. Sebagai contoh unsur "a" hanya bermakna jika "a" ini fungsional dalam kata atau kalimat. Misalnya "ayam berlari". Atas dasar ini metode global memperkenalkan membaca permulaan pada anak yang dimulai dengan memperkenalkan "kalimat". Kalimat dalam permainan untuk membangkitkan minat baca anak ini dapat dilakukan dengan menggunakan kalimat perintah. Contoh "ambil apel itu!" permainan ini dapat dilakukan dengan menggunakan kartu kalimat, kartu kata atau kartu huruf. Kegiatan permainan ini dapat dilakukan dengan menggunakan papan flanel dan karton yang dapat ditempel.

Berdasakan jalan pikiran penulis sebagaimana tertuang di atas, dapat diduga bahwa anak yang kurang ketrampilan membacanya dapat diatasi dengan menggunakan permainan membaca dengan kartu huruf dan kartu kata.

\section{METODE PENELITIAN}

Obyek penelitian tindakan kelas ini adalah proses permainan dengan media kartu huruf dan kartu kata serta ketrampilan membaca dan menulis anak. Sedangkan subyek penelitian adalah kelompok B1 TK PKK Putragiri semester II tahun pelajaran 2018/2019 dengan jumlah siswa 25 anak, terdiri dari 15 peserta didik laki-laki dan 10 peserta didik perempuan. Penelitian dilakukan pada bulan Januari 2019 s/d Maret 2019.

Penelitian tindakan kelas ini dilaksanakan menggunakan pendekatan penelitian tindakan kelas. Setiap siklus dilaksanakan dengan menyelesaikan 1 (satu) lingkup perkembangan selama 4 (empat) kali pertemuan. Siklus I dilaksanakan pada awal bulan Januari 2019 dan siklus II pada bulan Februari 2019. Setiap siklus dilaksanakan melalui 4 tahap, yaitu perencanaan, pelaksanaan tindakan, pengamatan, dan refleksi. 


\section{Perencanaan}

Pada tahap perencanaan ini penulis melakukan persiapan untuk melaksanakan tindakan antara lain;

a. Menyusun rancangan siklus 1 dan 2

b. Menyusun skenario pembelajaran siklus 1 dan 2

c. Menyusun rencana kegiatan harian

d. Membuat lembar kerja siswa dan menyusun petunjuk lembar kerja siswa yang akan dilaksanakan dalambercerita.

e. Menyanyikan format pengamatan dalam proses belajar mengajar tentang keaktifan peserta didik dalam melakukan permainan kartu huruf dan kartu kata

f. Menyiapkan format/instrumen penilaian

g. Menyiapkan media pembelajaran

\section{Pelaksanaan Tindakan}

Pada tahap pelaksanaan ini penulis yang sekaligus guru kelas B di TK PKK Putragiri melaksanakan pembelajaran dengan menggunakan metode permaianan kartu huruf dan kartu kata sesuai dengan rencana kegiatan harian yang telah disusun.

\section{Pengamatan}

Pada tahap pengamatan ini akan dilaksanakan pada saat pelaksanaan pembelajaran melalui metode permainan kartu huruf dan kartu kata, pengamatan yang dilakukan penulis dalam penelitian tindakan kelas ini adalah proses pembelajaran aktif melakukan kegiatan permainan kartu huruf dan kartu kata dengan kegiatan membaca dan menulis dengan menggunakan format pengamatan yang telah disediakan.

Aspek-aspek yang diamati pada proses pembelajaran antara lain meliputi ; kesesuaian antara apa yang dirancang dalam rpph dengan pelaksanaannya kemudian mengamati perubahan yang terkait dengan ketrampilan membaca dan menulis anak dan metode permainan kartu huruf dan kartu kata dengan. pengamatan keaktifan anak menggunakan alat penilaian, percakapan, pbservasi/pengamatan dan pencatatan Anecdotal record, digunakan untuk mencatat kejadian /perilaku khusus yang tidak biasa dilakukan anak sebelumnya catatan ini ditulis setelah pembelajaran selesai dan portofolio.

\section{Refleksi}

Data hasil pengamatan yang diperoleh selama proses belajar mengajar berlangsung yang berupaya hasil belajar siswa. Keaktifan siswa dan proses pembelajaran kemudian dianalisa secara deskriptif kualitatif. Berdasarkan hasil analisa ini penulis dan kolaborator melakukan refleksi diri untuk menentukan keberhasilan penelitian dan merencanakan tindakan berikutnya.

\section{Data dan Analisis Data}

Data yang dikumpulkan adalah data yang berkaitan dengan data hasil pengamatan tentang peningkatan minat baca dan kemampuan membaca dan menulis anak yang dikumpulkan dengan menggunakan alat penilaian dan penilaian di RKH selama pelaksanaan proses KBM.

\section{Indikator Kinerja}

Yang menjadi indikator keberhasilan pada penelitian tindakan kelas ini adalah sebagai berikut. Apabila lebih dari 85\% peserta didik menunjukkan minat baca yang tinggi serta aktif dalam membaca dan menulis dan aktif dalam permaianan membaca dan menulis telah mendapatkan nilai baik atau mendapat bintang 3 atau 4 .

\section{HASIL DAN PEMBAHASAN Pra siklus}

Hasil pengamatan ketrampilan membaca pra siklus adalah sebagai berikut:

Tabel 1. Ketrampilan membaca pra siklus

\begin{tabular}{|c|c|c|c|c|c|}
\hline \multirow[t]{2}{*}{ Siklus } & \multirow{2}{*}{$\begin{array}{l}\text { Jumlah } \\
\text { anak }\end{array}$} & \multicolumn{4}{|c|}{$\begin{array}{l}\text { Hasil pengamatan aktif } \\
\text { membaca }\end{array}$} \\
\hline & & * & $* *$ & $* * *$ & $* * * *$ \\
\hline I & 25 & 5 & 10 & 8 & 2 \\
\hline \multicolumn{2}{|c|}{ Prosentase } & $20 \%$ & $40 \%$ & $32 \%$ & $8 \%$ \\
\hline
\end{tabular}


Tabel 2. Rekapitulasi ketrampilan membaca

\begin{tabular}{clc}
\multicolumn{3}{c}{ pra siklus } \\
\hline No & \multicolumn{1}{c}{ Kategori } & Nilai \\
\hline 1 & Sangat aktif & 2 \\
2 & Aktif & 8 \\
3 & Kurang aktif & 10 \\
4 & Tidak aktif & 5 \\
\hline & Jumlah & 25 \\
\hline
\end{tabular}

Dari hasil pengamatan pada Pra siklus dari ketrampilan membaca adalah ada 5 anak (20\%) yang belum aktif atau tidak aktif dalam membaca hal ini karena anak belum paham dalam membedakan huruf abjad dan ada 8 anak (32\%) anak yang kurang aktif dalam membaca hal ini dikarenakan anak belum hafal huruf abjad, ada 10 (40\%) anak yang aktif dalam membaca serta ada 4 (16\%) anak yang sangat aktif dalam membaca.

Tabel 3. Ketrampilan menulis pra siklus

\begin{tabular}{|c|c|c|c|c|c|}
\hline \multirow[t]{2}{*}{ Siklus } & \multirow{2}{*}{$\begin{array}{c}\text { Jumlah } \\
\text { anak }\end{array}$} & \multicolumn{4}{|c|}{$\begin{array}{l}\text { Hasil pengamatan Aktif } \\
\text { menulis }\end{array}$} \\
\hline & & $*$ & $* *$ & $* * *$ & $* * * *$ \\
\hline I & 25 & 7 & 8 & 7 & 3 \\
\hline \multicolumn{2}{|c|}{ Prosentase } & $28 \%$ & $32 \%$ & $28 \%$ & $12 \%$ \\
\hline
\end{tabular}

Tabel 4. Rekapitulasi ketrampilan menulis pra siklus

\begin{tabular}{clc}
\hline No & \multicolumn{1}{c}{ Kategori } & Nilai \\
\hline 1 & Sangat aktif & 7 \\
2 & Aktif & 8 \\
3 & Kurang aktif & 7 \\
4 & Tidak aktif & 3 \\
\hline & Jumlah & 25 \\
\hline
\end{tabular}

Dari hasil pengamatan Pra siklus tentang hasil belajar ketrampilan menulis adalah ada 7 anak (28\%) yang belum aktif atau tidak aktif dalam menulis hal ini karena anak belum mampu menulis serta masih bingung cara menulis yang benar, ada 8 anak (32\%) yang kurang aktif dalam menulis, ada 7 anak (28\%) aktif dalam menulis serta ada 3 anak (12\%) sangat aktif dan tulisannya sudah bagus. Hasil pengamatan keaktifan anak dalam barmain pra siklus adalah sebagai berikut:
Tabel 5. Keaktifan bermain kartu kata dan kartu huruf pra siklus

\begin{tabular}{|c|c|c|c|c|c|}
\hline \multirow{2}{*}{ Siklus } & \multirow{2}{*}{$\begin{array}{c}\text { Jumlah } \\
\text { anak }\end{array}$} & \multicolumn{4}{|c|}{$\begin{array}{l}\text { Hasil pengamatan } \\
\text { keaktifan bermain kartu }\end{array}$} \\
\hline & & * & ** & $* * *$ & **** \\
\hline I & 25 & 6 & 6 & 9 & 4 \\
\hline Prose & entase & $24 \%$ & $24 \%$ & $36 \%$ & $16 \%$ \\
\hline
\end{tabular}
keaktifan bermain pra siklus disajikan pada tabel berikut ini:

Tabel 6. Rekapitulasi hasil belajar aktif bermain kartu kata dan kartu huruf pra siklus

\begin{tabular}{clc}
\hline No & \multicolumn{1}{c}{ Kategori } & Nilai \\
\hline 1 & Sangat aktif & 4 \\
2 & Aktif & 9 \\
3 & Kurang aktif & 6 \\
4 & Tidak aktif & 6 \\
\hline & Jumlah & 25 \\
\hline
\end{tabular}

Dari hasil pengamatan keaktifan anak dalam bermain kartu huruf dan kartu kata pra siklus adalah ada 6 anak (24\%) yang belum aktif atau tidak aktif dalam bermain kartu karena belum hafal nama huruf, ada 6 anak (24\%) kurang aktif dalam bermain kartu kata dan kartu huruf .hal ini dikarenakan kurang berminat bermain kartu.ada 9 anak (36\%) yang aktif dalam bermain kartu kata dan kartu huruf serta ada 4 anak (16\%) sangat aktif dalam bermain kartru kata dan kartu huruf.

\section{Siklus 1}

Pada sajian data siklus satu ini, penulis akan menyajikan perencanaan, pelaksanaan, observasi dan refleksi yang penulis lakukan ketika melakukan pembelajaran. Hasil pengamatan ketrampilan membaca siklus 1 disajikan pada tabel berikut ini:

Tabel 7. Ketrampilan membaca siklus 1

\begin{tabular}{cccccc}
\hline \multirow{2}{*}{ Siklus } & \multirow{2}{*}{$\begin{array}{c}\text { Jumlah } \\
\text { anak }\end{array}$} & \multicolumn{4}{c}{$\begin{array}{c}\text { Hasil pengamatan aktif } \\
\text { membaca }\end{array}$} \\
\cline { 2 - 6 } & $*$ & $* *$ & $* * *$ & $* * * *$ \\
\hline I & 25 & 2 & 3 & 16 & 4 \\
\hline Prosentase & $8 \%$ & $12 \%$ & $64 \%$ & $16 \%$ \\
\hline
\end{tabular}

Sedangkan rekapitulasi hasil belajar ketrampilan membaca siklus 1 disajikan pada tabel berikut ini: 
Tabel 8. Rekapitulasi ketrampilan membaca siklus 1

\begin{tabular}{clc}
\hline No & \multicolumn{1}{c}{ Kategori } & Nilai \\
\hline 1 & Sangat aktif & 4 \\
2 & Aktif & 16 \\
3 & Kurang aktif & 3 \\
4 & Tidak aktif & 2 \\
\hline & Jumlah & 25 \\
\hline
\end{tabular}

Dari hasil pengamatan pada siklus 1

dari ketrampilan membaca adalah masih ada 2 anak (8\%) yang belum aktif atau tidak aktif dalam membaca hal ini karena anak belum faham dalam membedakan huruf abjaddan masih ada 3 anak (12\%) anak yang kurang aktif dalam membaca hal ini dikarenakan anak belum hafal huruf abjad,ada 16 (64\%)anak yang aktif dalam membaca serta ada $4(16 \%)$ anak yang sangat aktif dalam membaca.

Tabel 9. Ketrampilan menulis siklus 1

\begin{tabular}{cccccc}
\hline \multirow{2}{*}{ Siklus } & \multirow{2}{*}{$\begin{array}{c}\text { Jumlah } \\
\text { anak }\end{array}$} & \multicolumn{4}{c}{ Hasil pengamatan } \\
\cline { 3 - 6 } & & $*$ & $* *$ & $* * *$ & $* * * *$ \\
\hline I & 25 & 1 & 4 & 15 & 5 \\
\hline Prosentase & $4 \%$ & $16 \%$ & $60 \%$ & $20 \%$ \\
\hline
\end{tabular}

Sedangkan rekapitulasi hasil belajar ketrampilan membaca siklus 1 disajikan pada tabel berikut ini:

Tabel 10. Rekapitulasi hasil belajar

ketrampilan menulis pada siklus 1

\begin{tabular}{clc}
\hline No & \multicolumn{1}{c}{ Kategori } & Nilai \\
\hline 1 & Sangat aktif & 5 \\
2 & Aktif & 15 \\
3 & Kurang aktif & 4 \\
4 & Tidak aktif & 1 \\
\hline & Jumlah & 25 \\
\hline
\end{tabular}

Dari hasil pengamatan siklus 1 tentang hasil belajar ketrampilan menulis adalah: Masih ada 1 anak (4\%) yang belum aktif atau tidak aktif dalam menulis hal ini karena anak belum mampu menulis serta masih bingung cara menulis yang benar.ada 4 anak (16\%) yang kurang aktif dalam menulis, ada 15 anak $(60 \%)$ aktif dalam menulis serta ada 5 anak (20\%) sangat aktif dan tulisannya sudah bagus
Hasil pengamatan keaktifan anak dalam barmain siklus 1 adalah sebagai berikut:

Tabel 11. Keaktifan bermain kartu kata dan kartu huruf siklus 1

\begin{tabular}{cccccc}
\hline \multirow{2}{*}{ Siklus $\begin{array}{c}\text { Jumlah } \\
\text { anak }\end{array}$} & \multicolumn{5}{c}{ Hasil pengamatan } \\
\cline { 2 - 6 } & $*$ & $* *$ & $* * *$ & $* * * *$ \\
\hline I & 25 & 1 & 3 & 15 & 6 \\
\hline Prosentase & $4 \%$ & $12 \%$ & $60 \%$ & $24 \%$ \\
\hline \multicolumn{5}{c}{ Sedangkan } & \multicolumn{3}{c}{ rekapitulasi } & tentang
\end{tabular}
keaktifan bermain siklus 1 disajikan pada tabel berikut ini:

Tabel 12. Rekapitulasi hasil belajar aktif bermain kartu kata dan kartu huruf siklus 1

\begin{tabular}{clc}
\hline No & \multicolumn{1}{c}{ Kategori } & Nilai \\
\hline 1 & Sangat aktif & 6 \\
2 & Aktif & 15 \\
3 & Kurang aktif & 3 \\
4 & Tidak aktif & 1 \\
\hline & Jumlah & 25 \\
\hline
\end{tabular}

Dari hasil pengamatan keaktifan anak dalam bermain kartu huruf dan kartu kata adalah : ada 1 anak (4\%) yang belum aktif atau tidak aktif dalam bermain kartu karena belum hafal nama huruf, ada 3 anak (12\%) kurang aktif dalam bermain kartu kata dan kartu huruf dikarenakan kurang berminat dengan bermain kartu, ada 15 anak (60\%) yang aktif dalam bermain kartu kata dan kartu huruf serta ada 6 anak (24\%) sangat aktif dalam bermain kartru kata dan kartu huruf.

\section{Siklus 2}

Pada sajian data siklus kedua ini penulis akan menyajikan perencanaan, pelaksanaan, observasi dan refleksi yang penulis lakukan ketika melakukan pembelajaran bermain kartu kata dan kartu huruf.

Hasil pengamatan ketrampilan membaca siklus 2 disajikan pada tabel berikut:

Tabel 13. Ketrampilan membaca siklus 2

\begin{tabular}{cccccc}
\hline \multirow{2}{*}{ Siklus $\begin{array}{c}\text { Jumlah } \\
\text { anak }\end{array}$} & \multicolumn{4}{c}{$\begin{array}{c}\text { Hasil pengamatan aktif } \\
\text { membaca }\end{array}$} \\
\cline { 2 - 6 } & $*$ & $* *$ & $* * *$ & $* * * *$ \\
\hline I & 25 & 0 & 1 & 10 & 14 \\
\hline Prosentase & $0 \%$ & $4 \%$ & $40 \%$ & $56 \%$ \\
\hline
\end{tabular}


Sedangkan rekapitulasi hasil belajar ketrampilan membaca siklus 1 disajikan pada tabel berikut ini:

Tabel 14. Rekapitulasi ketrampilan membaca siklus 2

\begin{tabular}{clc}
\hline No & \multicolumn{1}{c}{ Kategori } & Nilai \\
\hline 1 & Sangat aktif & 14 \\
2 & Aktif & 10 \\
3 & Kurang aktif & 1 \\
4 & Tidak aktif & 0 \\
\hline & Jumlah & 25 \\
\hline
\end{tabular}

Dari hasil pengamatan pada siklus 2 dari ketrampilan membaca adalah: sudah tidak ada anak yang belum aktif atau tidak aktif dalam membaca ,masih ada 1 anak (4\%) anak yang kurang aktif dalam membaca hal ini dikarenakan anak belum hafal huruf abjad, ada $10(40 \%)$ anak yang aktif dalam membaca serta ada $14(56 \%)$ anak yang sangat aktif dalam membaca.

Hasil pengamatan ketrampilan menulis siklus 2 disajikan pada tabel berikut:

Tabel 15. Ketrampilan menulis siklus 2

\begin{tabular}{cccccc}
\hline \multirow{2}{*}{ Siklus $\begin{array}{c}\text { Jumlah } \\
\text { anak }\end{array}$} & \multicolumn{4}{c}{ Hasil pengamatan aktif } \\
\cline { 2 - 6 } & $*$ & $* *$ & $* * *$ & $* * * *$ \\
\hline I & 25 & 0 & 0 & 15 & 10 \\
\hline Prosentase & $0 \%$ & $4 \%$ & $60 \%$ & $40 \%$ \\
\hline
\end{tabular}

Sedangkan rekapitulasi hasil belajar ketrampilan menulis siklus 1 disajikan pada tabel berikut ini:

Tabel 16. Rekapitulasi ketrampilan menulis siklus 2

\begin{tabular}{clc}
\hline No & \multicolumn{1}{c}{ Kategori } & Nilai \\
\hline 1 & Sangat aktif & 10 \\
2 & Aktif & 15 \\
3 & Kurang aktif & 0 \\
4 & Tidak aktif & 0 \\
\hline & Jumlah & 25 \\
\hline
\end{tabular}

Dari hasil pengamatan siklus 2 tentang hasil belajar ketrampilan menulis, tidak ada anak $(0 \%)$ yang belum aktif atau tidak aktif dalam menulis, tidak ada anak $(0 \%)$ yang kurang aktif dalam menulis, ada 15 anak $(60 \%)$ aktif dalam menulis serta ada 10 anak (40\%) sangat aktif dan tulisannya sudah bagus.
Hasil pengamatan keaktifan anak dalam barmain siklus 2 adalah sebagai berikut:

Tabel 17. Keaktifan bermain kartu kata dan kartu huruf siklus 2

\begin{tabular}{|c|c|c|c|c|c|}
\hline \multirow[t]{2}{*}{ Siklus } & \multirow{2}{*}{$\begin{array}{c}\text { Jumlah } \\
\text { anak }\end{array}$} & \multicolumn{4}{|c|}{$\begin{array}{c}\text { Hasil pengamatan } \\
\text { keaktifan bermain kartu }\end{array}$} \\
\hline & & * & $* *$ & $* * *$ & $* * * *$ \\
\hline I & 25 & 0 & 0 & 16 & 9 \\
\hline \multicolumn{2}{|c|}{ Prosentase } & $0 \%$ & $0 \%$ & $64 \%$ & $36 \%$ \\
\hline
\end{tabular}
keaktifan bermain siklus 2 disajikan pada tabel berikut ini:

Tabel 18. Rekapitulasi hasil belajar aktif bermain kartu kata dan kartu huruf siklus 2

\begin{tabular}{clc}
\hline No & \multicolumn{1}{c}{ Kategori } & Nilai \\
\hline 1 & Sangat aktif & 9 \\
2 & Aktif & 16 \\
3 & Kurang aktif & 1 \\
4 & Tidak aktif & 0 \\
\hline & Jumlah & 25 \\
\hline
\end{tabular}

Dari hasil pengamatan keaktifan anak dalam bermain kartu huruf dan kartu kata adalah: Tidak ada anak ( $0 \%)$ yang belum aktif atau tidak aktif dalam bermain kartu dan tidak ada anak (0\%) kurang aktif dalam bermain kartu kata dan kartu huruf, ada 16 anak (64\%) yang aktif dalam bermain kartu kata dan kartu huruf serta ada 6 anak (36\%) sangat aktif dalam bermain kartru kata dan kartu huruf.

\section{KESIMPULAN}

Dari hasil Penelitian Tindakan Kelas yang telah dilaksanakan dapat disimpulkan sebagai berikut: Penggunaan permainan kartu kata dan kartu huruf dapat meningkatkan ketrampilan membaca dan ketrampilan menulis pada anak di TK PKK Putragiri semester 2 Tahun Ajaran 2018/2019.

Keberhasilan suatu Pembelajaran sangat tergantung pada aktifitas dan kreatifitas guru, maka hendaknya guru dapat: 1) Memilih dan menerapkan metode yang tepat dalam pembelajaran 2) Mengelola kelas atau pembelajaran dengan sebaik-baiknya. 3) Memberikan pelayanan yang optimal kepada anak, baik secara individu, kelompok maupun 
klasikal. 4) Menggunakan atau memilih alat pembelajaran yang tepat.

Agar anak dapat berhasil dalam belajarnya, hendaknya: 1) Menaruh minat yang tinggi terhadap pembelajaran sehingga dapat memahami materi pembelajaran dengan baik. 2) Berkonsentrasi dalam mengikuti pembelajaran sehingga penjelasan guru dapat diserap dengan baik. 3) Selalu mengerjakan tugas yang diberikan guru dengan sungguhsungguh.

Sekolah hendaknya menciptakan iklim belajar yang kondusif,yang memungkinkan anak dapat belajar dengan tenang, aktif, kreatif, efektif dan menyenangkan sehingga anak merasa nyaman dan betah di sekolah serta dapat lebih konsentrasi dalam mengikuti pembelajaran tanpa ada gangguan baik dari dalam diri anak maupun dari luar. Sekolah hendaknya menyediakan media dan alat peraga yang memadai.serta memberikan kesempatan kepada guru untuk mengembangkan kemampuannya.

\section{DAFTAR PUSTAKA}

Agus Warsisto Dwi Doso Warso. (2012). Publikasi Ilmiah Melalui Penelitian Tindakan Kelas/Sekolah (PTK/PTS). Bogor: Graha Cendekia
Badruzaman, dkk. (2010). Media dan Sumber Belajar TK. Jakarta: Universitas Terbuka.

Departemen Pendidikan Nasional. (2005). Pedoman Pembelajaran di Taman Kanak-Kanak.Jakarta: Depdiknas.

Depdiknas. (2007). Pedoman Pembelajaran, Bidang Pengembangan Berbahasa, di Taman Kanak-kanak. Jakarta: Depdiknas

Depdiknas. (2007). Pedoman Pembelajaran Persiapan Membaca dan Menulis Permulaan Melalui Permainan di TK. Jakarta: Depdiknas

Suharsimi Arikunto. (2009). Prosedur Penelitian, Suatu Pendekatan Praktek. Jakarta: Rineka Cipta

Tim PKP PG-PAU. (2008). Pemantapan Kemampuan Profesional. Jakarta: Universitas Tebuka.

Tim PUDI Dikdasmen Lemlit UNY. (2008). Penelitian Tindakan Kelas. Yogyakarta: UNY

Winda Gunarti, dkk. (2007). Metode Pengembangan Perilaku dan Kemampuan Dasar AUD. Jakarta: Universitas Terbuka.

Winata, Udin S, dkk. (2005). Strategi Belajar Mengajar. Jakarta: Universitas Terbuka.

Winarno Surakhmad. (2010). Metodologi Penelitian. Bandung: Remadja Karya.. 